\title{
Paraneoplasic Leukemoid Reaction in Patient with Lung Carcinoma: Case Report and Literature Review
}

\author{
Yahyaoui Hicham*, A. Jahdaoui, S. Ed-dyb, Z. Et-Tahouri, M. Ait Ameur, M. Chakour
}

Hematology laboratory, Avicenne Military Hospital, Marrakesh, Morocco

\author{
DOI: $10.36348 /$ sjmps.2020.v06i03.008 \\ | Received: 07.03.2020 | Accepted: 19.03.2020 | Published: 30.03.2020 \\ *Corresponding author: Yahyaoui Hicham
}

\section{Abstract}

Leukemoid reaction is defined as leucocytosis $>50 \mathrm{G} / 1$. When it occurs in association with a malignancy, and infection or leukemia has been ruled out, it is termed as paraneoplastic leukemoid reaction. We report a case of a patient presented with fatigue, generalized weakness, and was incidentally noted to have a white blood cell count of 139G/l. Leukemia was ruled out by peripheral smear and flow cytometry. Computed tomography-guided biopsy of thickened omentum revealed poorly differentiated metastatic carcinoma. Leukemoid reaction is a diagnosis which must be evoked in front of any extreme hyperleukocytosis apart from associated infectious or hematological situations. This syndrome has an extremely pejorative prognostic value.

Keywords: Leukemoid reaction, lung, carcinoma, leucocytosis, prognosis.

Copyright @ 2020: This is an open-access article distributed under the terms of the Creative Commons Attribution license which permits unrestricted use, distribution, and reproduction in any medium for non-commercial use (NonCommercial, or CC-BY-NC) provided the original author and source are credited.

\section{INTRODUCTION}

Leukemoid reaction is defined as a white blood cell count (WBC) more than 50G/1 with predominance of neutrophil precursors [1].

Although it can occur in severe infection, it can also present as a paraneoplasic syndrome in patients with a variety of cancers. Lung, esophageal, nasopharyngeal and laryngeal, gastric, cholangiocarcinoma, melanoma, multiple myeloma, bladder, kidney, prostate, and hepatocellular carcinomas have all been reported to be associated with this condition.

The underlying mechanism appears to be the production of growth factors such as granulocyte macrophage colonystimulating factor (GM-CSF), granulocyte CSF (G-CSF), and interleukins (IL-3 and IL-6) that are produced by the tumor cells [2].

We present a case of a 64-year-old man who was admitted with increasing fatigue, generalized weakness, and chronic caugh and leucocytosis (185G/1), thoracic CT founded an apical nodul of the left lung and the bronchoscopy guided the biopsy. The histological analasys showed a lung adenocarcinoma.
The aim of our study is to repport our case and review the literature to present other reported cases of leukemoid reaction in association with solid tumors and discuss potential causative mechanisms.

\section{Observation}

It is a 64-year-old man, chronic smoking, diagnosed with an apical adenocarcinoma of the left lung stage IIIA, revealed by a dry cough, asthenia and a major hyperleukocytosis with an hemogram of about $132 \mathrm{G} / \mathrm{l}$. At the very beginning and before performing the chest CT (Figure-1) and bronchoscopy, the practitioner thought of a malignant hemopathy in front of the hyperleukocytosis, which pushed to carry out a blood smear and a bone marrow smear. The blood smear confirmed the neutrophilic hyperleukocytosis predominantly with myelemia (Figure-2A) whereas the myelogram objectified hyperplasia of the granular line with absence of blasts or extra-hematopoietic cells (Figure-2B).

After the initiation of cancer therapy, the white blood cell count started to drop (Figure-3), suggesting a paraneoplastic hyperleukytosis. 


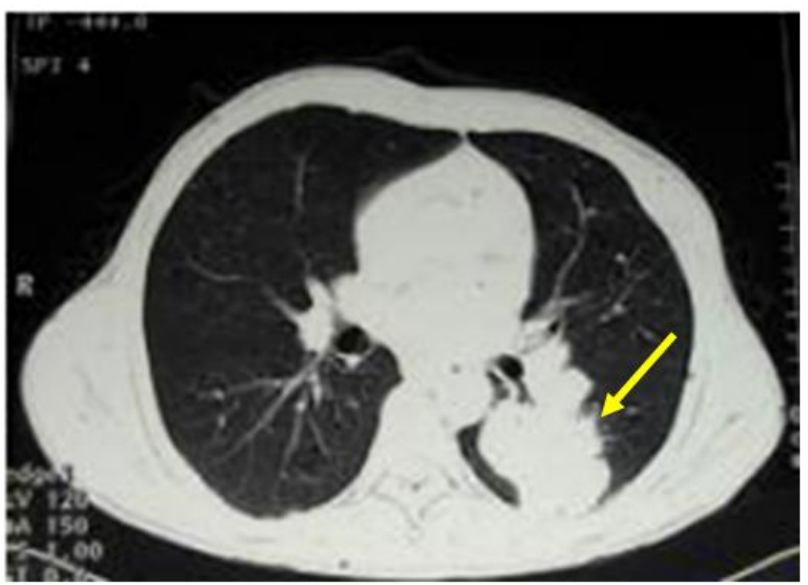

Fig-1: Chest CT scan showing an irregular nodule in the apical lobe of the left lung

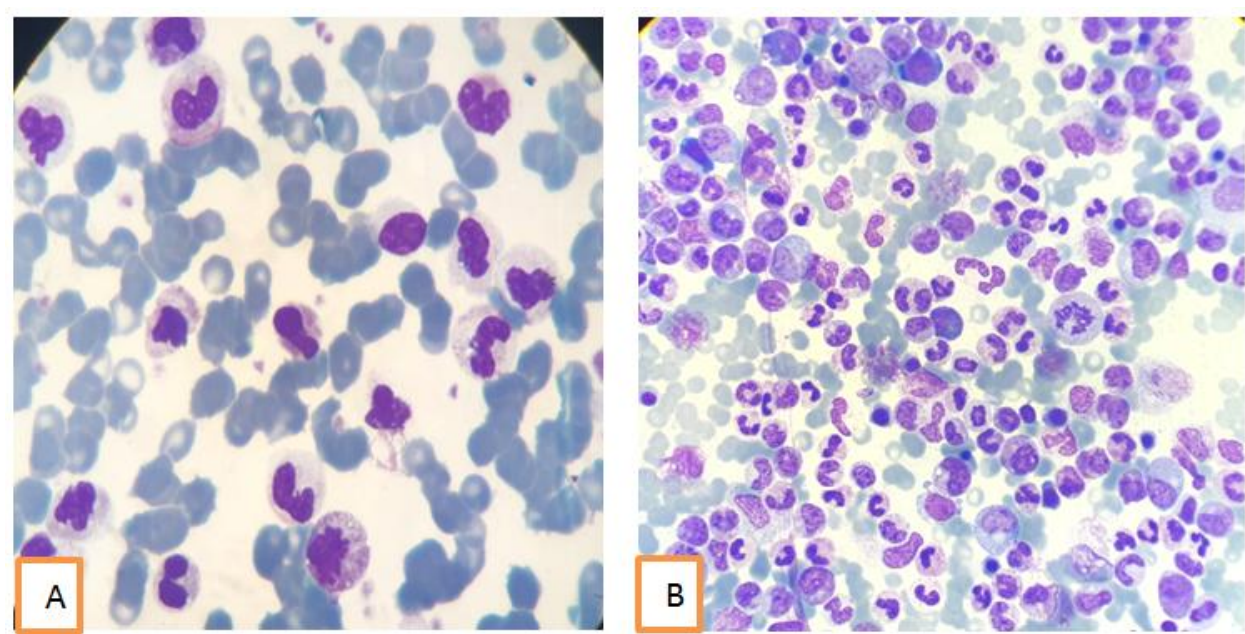

Fig-2A: polynuclear neutrophils in peripheral blood smear (may grunwald $\times 1000)$ B) granular hyperplasia in marrow smear (may grunwald $\times 500)$

Table-1: White blood cells account

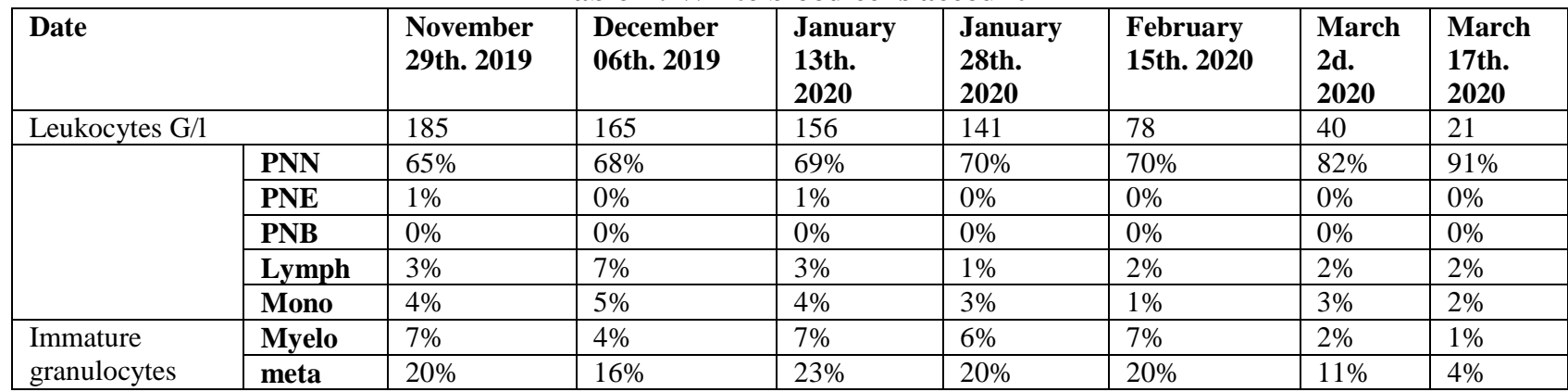

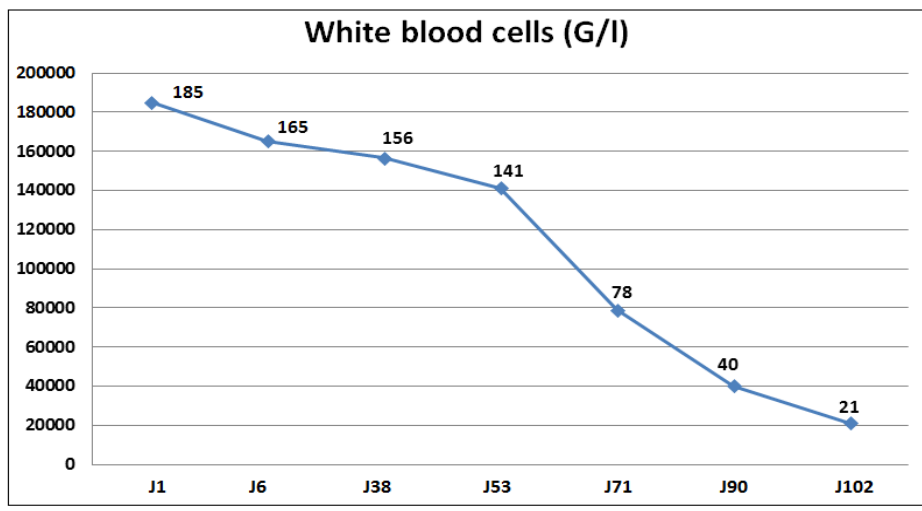

Fig-3: The evolution of white blood cells during the survey of hemogram after treatment 


\section{DISCUSSION}

Paraneoplasic syndromes (PNS) are defined as effects distant from the site of the primary tumor that are produced by substances released from tumor cells but not due to direct tissue invasion by the primary tumor or its metastases.

Several categories of PNS exist including cutaneous, hematologic, rheumatologic, endocrine, neurologic, and ocular manifestations [3].

Not much is known about the incidence and course of leukaemoid reactions. Most knowledge is based on case reports [4-10]. Several known causes of leukaemoid reactions are given in table 2. A paraneoplastic leukaemoid reaction can be caused by increased serum levels of G-CSF or other growth factors, which are considered to be produced by the malignant cells, mostly from an endothelial tumour [57].

In some reports, a decrease in G-CSF levels was described after treatment of the primary tumour [8]. The leukemoid reaction can be present even years before the diagnosis of the carcinoma [9].

Table-2: Several causes of a leukemoid reaction [11]

\begin{tabular}{|l|}
\hline Infectious : \\
\hline Shigellosis \\
Hepatic abscess \\
Tuberculosis \\
Sepsis \\
\hline Paraneoplastic : \\
\hline Bronchus carcinoma \\
Carcinoma of bladder, kidney and prostate \\
Carcinoma of tongue and nasopharynx \\
Carcinoid \\
Hepatocellular carcinoma \\
Carcinoma of oesophagus \\
Cholangiocarcinoma \\
Carcinoma of cervix or ovary \\
Splenic haemangiosarcoma \\
Liposarcoma and soft tissue sarcoma \\
Leiomyosarcoma of the bladder \\
Melanoma \\
Bone metastasis \\
Multiple myeloma \\
Hodgkin's disease \\
\hline Drug induced : \\
\hline Granulocyte colony stimulating factor \\
Corticosteroids \\
Tetracycline \\
Streptokinase \\
\hline Miscellaneous : \\
\hline Diabetic ketoacidosis \\
Alcoholic hepatitis \\
Ethylene glycol intoxication \\
Enteric necrosis \\
\hline
\end{tabular}

A paraneoplasic leukemoid reaction (PLR) is a hematologic PNS that has been defined in the literature as leucocytosis $>20$ to $50 \mathrm{G} / 1$ and described in association with different solid tumors. Neutrophils are generally the predominant white cell type in these cases. However, there have been case reports of PLR wherein the predominant cell types were eosinophils $[12,13]$.

Leucocytosis in our patient exceeded $100 \mathrm{G} / \mathrm{l}$ with neutrophilia predominance joining thus the majority of studies about paraneoplasic leucocytosis in litterature (Table-3). 
Yahyaoui Hicham et al; Saudi J Med Pharm Sci, March., 2020; 6(3): 306-310

Table-3: Selected Case Reports on Leukemoid Reaction in lung Solid Tumors

\begin{tabular}{|c|c|c|c|}
\hline Series & Type of lung cancer & $\begin{array}{l}\text { WBC Count at } \\
\text { Presentation }(\text { G/l) }\end{array}$ & $\begin{array}{l}\text { Differential } \\
\text { Count }\end{array}$ \\
\hline Chakraborty [14] & Poorly differentiated Carcinoma & 139 & Neutrophilia \\
\hline Shalom G [15] & Poorly differentiated large cell carcinoma & 15 & Neutrophilia \\
\hline Shalom G [15] & Poorly differentiated squamous cell carcinoma & 28 & Neutrophilia \\
\hline Ganti AK [16] & Non-small cell lung cancer & 71 & Neutrophilia \\
\hline Mukhopadhyay S [17] & Non-small cell lung cancer & 52 & Neutrophilia \\
\hline Dalal PR [18] & Giant cell carcinoma & 11 & Neutrophilia \\
\hline Riesenberg H [19] & Lung adenocarcinoma & 21 & Neutrophilia \\
\hline Lammel V [3] & Large cell lung cancer & 77 & Eosinophilia \\
\hline Our study & Lung adenocarcinoma & 185 & Neutrophilia \\
\hline
\end{tabular}

Most reviewed studies have reported an association between elevated levels of a particular cytokine and leucocytosis. The levels of IL-1a, b, IL-3, G-CSF, GM-CSF, IL-6, and TNF-a have all been reported to be elevated in various solid tumors and suggested to contribute to an elevated leukocyte count [20]. We reviewed the Medline database through PubMed for articles describing leukemoid reaction in association with solid tumors.

Watanabe and colleagues, for instance, described a case of PLR associated with non-small cell cancer of the lung, wherein the serum GM-CSF levels were markedly elevated (77 times higher than normal). Tumor cells expressed both GM-CSF and its cognate receptor, suggesting that PLR was a "side effect" of paracrine growth.

Serum GM-CSF levels were also elevated together with increased expression of GM-CSF and GM-CSF receptor by non-small cell cancer cells and by eosinophils in another reported case of PLR [21].

Literature review shows that lung cancer with a leukaemoid reaction is associated with aggressive tumour behaviour and high mortality [14].

Table-4: Mortality in literature.

\begin{tabular}{|l|l|l|}
\hline Séries & Type of cancer & Taux de mortalité \\
\hline Chakraborty [14] & Poorly differentiated Carcinoma & Died 3 d after presentation \\
\hline Shalom G [15] & Poorly differentiated large cell carcinoma of lung & Died 7mo after diagnosis \\
\hline Shalom G [15] & Poorly differentiated squamous cell carcinoma & Died 4mo after diagnosis \\
\hline Ganti AK [16] & Non-small cell lung cancer & Died before chemotherapy could be started \\
\hline Mukhopadhyay S [17] & Non-small cell lung cancer & $\begin{array}{l}\text { Died 4wk after diagnosis despite } \\
\text { Chemoradiation }\end{array}$ \\
\hline Dalal PR [18] & Giant cell carcinoma of the Lung & Died 3.5mo after presentation \\
\hline Riesenberg H [19] & Lung adenocarcinoma & Died 5mo after diagnosis \\
\hline Lammel V [3] & Large cell lung cancer & Died 2mo after diagnosis \\
\hline Notre étude & Lung adenocarcinoma & alive \\
\hline
\end{tabular}

\section{CONCLUSION}

Leukocyte counts in excess of 20,000 should always prompt workup aimed at distinguishing leukemia from a leukemoid reaction.

Initial tests should include at least a peripheral smear looking for blasts, an infectious signs. This syndrome could have a poorer prognostic value for patients with lung cancer.

\section{REFERENCES}

1. Lefebvre, M., Talarmin, J. P., Cariou, B., \& Hamidou, M. (2009). Hyperleucocytose paranéoplasique extrême: à propos de deux cas et revue de la littérature. $L a$ Revue de médecine interne, (30), S421.

2. Chakraborty, S., Keenportz, B., Woodward, S., Anderson, J., \& Colan, D. (2015). Paraneoplastic leukemoid reaction in solid tumors. American journal of clinical oncology, 38(3), 326-330.

3. Lammel, V., Stoeckle, C., Padberg, B., Zweifel, R., Kienle, D. L., Reinhart, W. H., \& Simon, H. U. (2012). Hypereosinophilia driven by GM-CSF in large-cell carcinoma of the lung. Lung Cancer, 76(3), 493-495.

4. De Wolff, J. F., Planken, E. V., \& den Ottolander, G. J. (2004). Extreme leucocytosis and splenomegaly in metastasised melanoma. Neth $J$ Med, 62(5), 164-7.

5. Horii, A., Shimamura, K., Honjo, Y., Mitani, K., Miki, T., Takashima, S., \& Yoshida, J. I. (1997). Granulocyte colony stimulating factor- producing tongue carcinoma. Head \& Neck: Journal for the Sciences and Specialties of the Head and Neck, 19(4), 351-356.

6. Wetzler, M., Estrov, Z., Talpaz, M., Markowitz, A., Gutterman, J. U., \& Kurzrock, R. (1993). 
Granulocyte- macrophage colony- stimulating factor as a cause of paraneoplastic leukaemoid reaction in advanced transitional cell carcinoma. Journal of internal medicine, 234(4), 417-420.

7. Hocking, W., Goodman, J., \& Golde, D. (1983). Granulocytosis associated with tumor cell production of colony-stimulating activity. Blood, 61;600-603.

8. Nimieri, H. S., Makoni, S. N., Madziwa, F. H., \& Nemiary, D. S. (2003). Leukemoid reaction response to chemotherapy and radiotherapy in a patient with cervical carcinoma. Annals of hematology, 82(5), 316-317.

9. Ferrer, A., Cervantes, F., Hernández-Boluda, J. C., Alvarez, A., \& Montserrat, E. (1999). Leukemoid reaction preceding the diagnosis of colorectal carcinoma by four years. Haematologica, 84(7), 671-672.

10. McKee, J. L. (1985). Excess leukocytosis (leukemoid reactions) associated with malignant diseases. Southern medical journal, 78(12), 14751482.

11. Halkes, C. J., Dijstelbloem, H. M., Eelkman Rooda, S. J., \& Kramer, M. H. (2007). Extreme leucocytosis: not always leukaemia. Neth $J$ Med, 65(7), 248-51.

12. Miller, J. I., Sarver, R. G., \& Drach, G. W. (1994). Leukemoid reaction: a rare paraneoplastic syndrome associated with advanced bladder carcinoma. Urology, 44(3), 444-446.

13. Varindani, M. K., Pitchumoni, C. S., \& Lucariello, R. J. (1982). Eosinophilic leukemoid reaction in pulmonary carcinoma. New York state journal of medicine, 82(3), 347-348.
14. Chakraborty, S., Keenportz, B., Woodward, S., Anderson, J., \& Colan, D. (2015). Paraneoplastic leukemoid reaction in solid tumors. American journal of clinical oncology, 38(3), 326-330.

15. Shalom, G., Sion-Vardy, N., Dudnik, J., \& Ariad, S. (2010). Leukemoid reaction in lung cancer patients. The Israel Medical Association journal: IMAJ, 12(4), 255-256.

16. Ganti, A. K., Potti, A., \& Mehdi, S. (2003). Case 2. Metastatic non-small-cell lung cancer presenting with leukocytosis. Journal of clinical oncology, 21(1), 168-170.

17. Mukhopadhyay, S., Mukhopadhyay, S., Banki, K., \& Mahajan, S. (2004). Leukemoid reaction: a diagnostic clue in metastatic carcinoma mimicking classic Hodgkin lymphoma. Archives of pathology \& laboratory medicine, 128(12), 1445-1447.

18. Dalal, P. R., Rosenthal, R., \& Sarkar, T. K. (1980). Leukemoid reaction in pulmonary carcinoma. Journal of the National Medical Association, 72(7), 683-686.

19. Riesenberg, H., Müller, F., \& Görner, M. (2012). Leukemoid reaction in a patient with adenocarcinoma of the lung: a case report. Journal of medical case reports, 6(1), 211.

20. Azuma, T., Sakai, I., Matsumoto, T., Ozawa, A., Tanji, N., Watanabe, A., ... \& YASUKAWA, M. (2005). Leukemoid reaction in association with bone marrow necrosis due to metastatic prostate cancer. Internal Medicine, 44(10), 1093-1096.

21. Watanabe, M., Ono, K., Ozeki, Y., Tanaka, S., Aida, S., \& Okuno, Y. (1998). Production of Granulocyte-macrophage Colony-stimulating Factor in a Patient with Metastatic Chest Wall Large Cell Carcinoma. Japanese journal of clinical oncology, 28(9), 559-562. 